\title{
Ovulation and lambing rates in ewes actively immunized against androstenedione
}

\author{
P. F. A. Van Look*, I. J. Clarke†, W. G. Davidson \\ and R. J. Scaramuzzi \\ M.R.C. Unit of Reproductive Biology, 2 Forrest Road, Edinburgh, U.K.
}

\begin{abstract}
Summary. In ewes immunized against androstenedione, ovulation rate was increased $(P<0.001)$ although the number of live lambs/nursing ewe (1.37), but not the sex ratio $\left(10\right.$ of $\left.: 1 \delta^{\dagger}\right)$, was similar to that of controls $(1 \cdot 33)$.
\end{abstract}

\section{Introduction}

Despite intensive research no widely accepted practical method has yet been developed to increase reproductive performance in domestic animals (see Dziuk, 1973, for review). Present techniques such as the use of exogenous gonadotrophins to induce multiple follicular development and superovulation are in general expensive, unreliable and difficult to apply on a large scale. Moreover, the effectiveness of such methods in terms of promoting multiple births is often far less evident than their ability to stimulate maturation of many follicles because a higher than usual proportion of oocytes are not ovulated or remain unfertilized (Dziuk, 1973). We have previously demonstrated that active immunization of sheep against androstenedione results in an increased secretion of $\mathbf{L H}$ from the pituitary during anoestrus (Martensz, Baird, Scaramuzzi \& Van Look, 1976). During the mating season it was noted that the ovulation rate was twice as high in immunized ewes as in controls (Scaramuzzi, Davidson \& Van Look, 1977). However, the number of observations in the latter study was small and data were not obtained on the effect of immunization against androstenedione on lambing rate (i.e. number of live-born lambs per mated ewe). The present study was undertaken to obtain this information.

\section{Materials and Methods}

Welsh Mountain ewes were randomly divided into experimental $(\mathrm{N}=18)$ and control $(\mathrm{N}=7)$ groups. For primary immunization experimental ewes were given a s.c. injection of $1.0 \mathrm{mg} 11 \alpha$ hydroxyandrostenedione-bovine serum albumin (androstenedione-11-BSA) dissolved in $2 \mathrm{ml}$ $0.9 \%(\mathrm{w} / \mathrm{v}) \mathrm{NaCl}$ and emulsified with $2 \mathrm{ml}$ Freund's complete adjuvant (Difco Laboratories, Detroit, USA); control ewes were immunized with $1.0 \mathrm{mg}$ BSA. All ewes were also given an i.m. injection of $0.5 \mathrm{ml}$ pertussis vaccine (Burroughs Wellcome, Beckenham, Kent, U.K.) as an additional adjuvant. Booster injections of $1.0 \mathrm{mg}$ androstenedione-11-BSA or BSA were given 12 and 59 weeks after primary immunization. For each ewe an estimate of ovulation rate was obtained by taking the mean of the number of corpora lutea counted during laparotomy at 16 and 60 weeks after primary immunization. At 4 weeks after the first laparotomy the ewes were mated with 3 Welsh Mountain rams of proven fertility and pregnancies were allowed to proceed to term.

\section{Results}

Table 1 summarizes the results obtained in the 22 ewes investigated to term. Two experimental ewes died for undetermined reasons after the first laparotomy and 1 experimental ewe had extensive pelvic and abdominal adhesions which prevented inspection of the ovaries at the second laparotomy. The higher ovulation rate in the immunized ewes confirms our previous findings (Scaramuzzi et al.,

* Present address: Vrouwenkliniek, Academisch Ziekenhuis Leiden, Rijnsburgerweg 10, Leiden, The Netherlands.

$\uparrow$ Present address: S.S. Cameron Laboratory, Werribee, Victoria 3030, Australia.

†resent address: CSIRO Division of Animal Production, Prospect, P.O. Box 239, Blacktown 2148, New South Wales, Australia. 
Table 1. Mean ( \pm s.e.m.) ovulation rate and lambing performance of ewes actively immunized against androstenedione

\begin{tabular}{lccc}
\hline & $\begin{array}{c}\text { Control ewes } \\
(\mathrm{N}=7)\end{array}$ & $\begin{array}{c}\text { Immunized ewes } \\
(\mathrm{N}=15)\end{array}$ & $P$ \\
\hline Ovulation rate & $1 \cdot 36 \pm 0 \cdot 14$ & $2 \cdot 40 \pm 0 \cdot 17$ & $<0.001^{*}$ \\
No. of lambs born (singletons, twins) & $8(4,2)$ & $12 \ddagger(4,4)$ & N.S. $\dagger$ \\
Lambing rate & $1 \cdot 14 \pm 0 \cdot 26$ & $0 \cdot 73 \pm 0 \cdot 20$ & N.S. $^{*}$ \\
No. of lambing ewes & 6 & 8 & N.S. $\dagger$ \\
No. of live lambs per nursing ewe & 1.33 & 1.37 & N.S. $\dagger$ \\
Sex ratio of lambs $\left(+: 0^{*}\right)$ & $4: 4$ & $10: 1 \S$ & \\
\hline
\end{tabular}

* Student's $t$ test.

+ Not significant by $\chi^{2}$ with correction for continuity on $2 \times 2$ contingency table.

$\ddagger$ Including one stillborn twin lamb.

$\S$ The sex of one lamb was not recorded. The observed ratio was significantly $(P<0.05)$ different from the expected $1: 1$ ratio.

1977). The lambing rate, however, appeared to be adversely affected by the immunization procedure. Immunized ewes that did not lamb had significantly $(P<0.05)$ higher ovulation rates at laparotomy $(2 \cdot 79 \pm 0.24$, s.e.m., $N=7)$ than those that lambed $(2.06 \pm 0 \cdot 17, N=8)$.

Ovulation rates in the experimental lambing ewes were significantly $(P<0.01)$ higher than those in controls, but the number of lambs per nursing ewe was similar in both groups (Table 1). None of the 5 immunized animals with an ovulation rate of 3 or more produced live offspring. Plasma titres of androstenedione antibodies, determined as described previously (Martensz et al., 1976), ranged from $<1 / 100$ to $1 / 4000$ and were on average higher (geometric mean: 1/569) in animals with 3 or more corpora lutea than in the rest of the group (geometric mean: $1 / 223$ ).

\section{Discussion}

The present study shows that active immunization against androstenedione causes consistent increases in the ovulation rates of Welsh Mountain ewes as judged from the higher number of corpora lutea in immunized animals. The higher ovulation rates are probably the result of increased gonadotrophin secretion, observed in immunized animals during anoestrus (Martensz et al., 1976) and the breeding season (Scaramuzzi \& Martensz, 1975). The cause of the adverse effects of the immunization procedure in its present form on conception and lambing rate remains to be determined. The possibility that the observed discrepancy between ovulation and lambing rate in immunized ewes may be due to a reduced survival of male fetuses in these animals (Table 1) is presently under investigation.

We are grateful to Dr G. Woods, Organon Laboratories, Newhouse, Scotland, for providing the androstenedione-11 $\alpha$-hemisuccinyl and to Dr P. Dean for preparing the androstenedione-11-BSA conjugate. P.F.A.V.L. was supported by the Nationaal Fonds voor Wetenschappelijk Onderzoek, Brussels, Belgium. We also thatk Professor R. V. Short for reviewing the manuscript.

\section{References}

DzruK, P. (1973) Occurrence, control and induction of ovulation in pigs, sheep and cow. In Handbook of Physiology, Section 7, Endocrinology, Volume 2, Female Reproductive System, part 1, pp. 143-152. Eds R. O. Greep \& E. B. Astwood. Am. Physiol. Soc., Washington D.C.

Martensz, N.D., Baird, D.T., ScaramuzzI, R.J. \& VAN Look, P.F.A. (1976) Androstenedione and the control of luteinizing hormone in the ewe during anoestrus. J. Endocr. 69, 227-237.
Scaramuzzi, R.J. \& Martensz, N.D. (1975) The effects of active immunization against androstenedione on luteinizing hormone levels in the ewe. In Immunization with Hormones in Reproduction Research, pp. 141-152. Ed. E. Nieschlag. North Holland Publishing Company, Amsterdam, The Netherlands.

Scaramuzzi, R.J., Davidson, W.G. \& Van Look, P.F.A. (1977) Increasing ovulation rate in sheep by active immunization against an ovarian steroid androstenedione. Nature, Lond. 269, 817-818. 